\title{
Oil Consumption-pollution Dynamics in the Asia-Pacific Region: The Importance of Institutional Factors
}

\author{
Devi Prasad Dash ${ }^{1}$ (D), Aruna Kumar Dash² (D) \\ ${ }^{1}$ School of Management and Entrepreneurship, Indian Institute of Technology, Jodhpur, India, ${ }^{2}$ Department of Economics, IBS-Hyderabad, IFHE \\ University, Hyderabad, India \\ Keywords: Institutional factors, oil consumption, pollution dynamics, APEC Region, Quantile Estimates, JEL E31 E37 F37 \\ https://doi.org/10.46557/001c.30058
}

\section{Energy RESEARCH LETTERS}

Vol. 3, Issue 1, 2022

We evaluate the importance of institutional factors in influencing the emission intensity in 21 Asia-Pacific Economic Cooperation economies from 2000 to 2019. We show that rising corruption and decreasing governance quality exert positive impacts on pollution in addition to a positive association between oil consumption and pollution. We further note that increasing economic freedom and regulatory standards significantly help reduce pollution. However, the relation between human development and pollution is found to be mixed across our empirical models.

\section{Introduction}

In this paper, we examine the role of institutional factors influencing the pollution dynamics in Asia-Pacific Economic Cooperation (APEC) countries. The increase in population growth, urbanization, and industrialization increases economic activities and contributes to degrading the environment by increasing CO2 emissions. Franco et al. (2017) find that urbanization enhances the quality of life while fostering economic growth; nevertheless, urbanization also increases energy consumption and has a consequential impact on CO2. The rise in economic activity increases energy demand, which further increases $\mathrm{CO} 2$ emissions. Fossil fuel consumption (which involves coal, natural gas, and crude oil) is treated as a primary source of energy consumption increasing $\mathrm{CO} 2$ emissions and degrading environmental quality. Burke and Stephens (2018), Olanrewaju et al. (2019), and Zhao and Luo (2017) emphasize that replacing fossil fuel-based resources with renewable energy results in enhancing the environmental quality and reducing $\mathrm{CO} 2$ emissions.

We explore whether institutional quality plays a significant role in combating CO2 pollution. Ali et al. (2019) and Ibrahim and Law (2016) demonstrate that good governance mechanisms and institutional quality are key to ensuring more sustainable green development. When the institutional quality is high, environmental quality is highly likely to be strengthened (Yameogo et al., 2020). Singhania and Saini (2021) find that the institutional environmental law standards of the host economies are related to the quality of the environment. These institutional factors can have either a favorable or unfavorable effect on environmental policy. For instance, if the institutional factor has a significant and positive coefficient, the host country has lax en- vironmental policies resulting in higher $\mathrm{CO} 2$ emissions. On the other hand, if the institutional factor has a high negative coefficient, the host country has standard environmental frameworks that minimize carbon emissions (Xie et al., 2019). Tamazian et al. (2009) find that countries with a strong institutional structure have lower carbon emissions, due to strict regulatory norms. Mavragani et al. (2016) find that environmental performance is enhanced with institutional quality.

Khan et al. (2021) find that political stability reduces CO2 emissions and plays a beneficial role in environmental quality. Control of corruption reduces bribery between different parties, which raises the quality of the environment and diminishes the negative impact on $\mathrm{CO} 2$ emissions. Fredriksson and Svensson (2003) find that environmental policies are loosened in the presence of higher levels of corrupt practices and political upheavals. Mehrara et al. (2015) find that corruption activities reduce productive investments. Investments in high-cost renewable energy source projects are major risks for investors in highly corrupt economies. Ibrahim and Law (2016) find that greater trade openness hampers the environmental quality of economies with weak institutional mechanisms, whereas it positively impacts environmental quality in economies with stronger institutions. Egbetokun et al. (2020) find that increases in education expenditures for a couple of decades are associated with a significant reduction in $\mathrm{CO} 2$ pollution and temperatures in Nigeria.

To summarize, the success of pollution control policies depends on the quality of a country's institutions, where institutional quality is measured by a regulatory index. Countries that have instituted rules and regulations and sufficiently strong institutions can reduce environmental 
Table 1. Correlation Matrix

\begin{tabular}{|c|c|c|c|c|c|c|c|c|c|}
\hline & Ico2 & loil & Igeed & Iсpi & $\lg d p$ & lef & goe & $r q$ & hdi \\
\hline Ico2 & 1.000 & & & & & & & & \\
\hline loil & $\begin{array}{l}0.088^{* *} \\
(0.066)\end{array}$ & 1.000 & & & & & & & \\
\hline Igeed & $\begin{array}{c}0.064 \\
(0.062)\end{array}$ & $\begin{array}{l}-0.798 \\
(0.721)\end{array}$ & 1.000 & & & & & & \\
\hline Iсpi & $\begin{array}{l}-0.234^{*} \\
(0.000)\end{array}$ & $\begin{array}{l}0.388^{*} \\
(0.000)\end{array}$ & $\begin{array}{l}0.109^{*} \\
(0.025)\end{array}$ & 1.000 & & & & & \\
\hline $\lg d p$ & $\begin{array}{c}0.050 \\
(0.042)\end{array}$ & $\begin{array}{l}0.134^{*} \\
(0.023)\end{array}$ & $\begin{array}{c}-0.089^{* *} \\
(0.062)\end{array}$ & $\begin{array}{c}-0.080^{* *} \\
(0.054)\end{array}$ & 1.000 & & & & \\
\hline lef & $\begin{array}{l}-0.150^{*} \\
(0.000)\end{array}$ & $\begin{array}{l}0.438^{*} \\
(0.000)\end{array}$ & $\begin{array}{c}0.042 \\
(0.041)\end{array}$ & $\begin{array}{l}0.681^{*} \\
(0.004)\end{array}$ & $\begin{array}{c}0.066 \\
(0.062)\end{array}$ & 1.000 & & & \\
\hline goe & $\begin{array}{l}-0.241^{*} \\
(0.000)\end{array}$ & $\begin{array}{l}0.239^{*} \\
(0.000)\end{array}$ & $\begin{array}{l}0.123^{*} \\
(0.011)\end{array}$ & $\begin{array}{l}0.739^{*} \\
(0.000)\end{array}$ & $\begin{array}{l}-0.178^{*} \\
(0.003)\end{array}$ & $\begin{array}{l}0.251^{*} \\
(0.003)\end{array}$ & 1.000 & & \\
\hline rq & $\begin{array}{l}-0.321^{*} \\
(0.002)\end{array}$ & $\begin{array}{l}0.145^{*} \\
(0.002)\end{array}$ & $\begin{array}{l}0.174^{*} \\
(0.001)\end{array}$ & $\begin{array}{l}0.714^{*} \\
(0.003)\end{array}$ & $\begin{array}{c}-0.200^{*} \\
(0.002)\end{array}$ & $\begin{array}{l}0.237^{*} \\
(0.002)\end{array}$ & $\begin{array}{l}0.942^{*} \\
(0.007)\end{array}$ & 1.000 & \\
\hline hdi & $\begin{array}{l}-0.263^{*} \\
(0.003)\end{array}$ & $\begin{array}{l}0.382^{*} \\
(0.002)\end{array}$ & $\begin{array}{l}0.121^{*} \\
(0.012)\end{array}$ & $\begin{array}{l}0.704^{*} \\
(0.003)\end{array}$ & $\begin{array}{l}-0.263^{*} \\
(0.000)\end{array}$ & $\begin{array}{l}0.209^{*} \\
(0.003)\end{array}$ & $\begin{array}{l}0.846^{*} \\
(0.002)\end{array}$ & $\begin{array}{l}0.844^{*} \\
(0.001)\end{array}$ & 1.000 \\
\hline
\end{tabular}

This table shows the correlation between variables used in our analysis. The estimates suggest that oil consumption and carbon emission are positively correlated. Note that correlation coefficients and p-values are reported outside and inside the parentheses, respectively.

pollution, whereas countries with weak environmental regulations might not be able to control environmental degradation.

The objective of this paper is to examine the role of institutional factors influencing the pollution dynamics in the APEC region. Our study contributes to the literature in two aspects. First, this paper is unique in that it examines the role of institutions in determining the dynamics of oil consumption and pollution in the APEC region. Second, our study uses the latest data on 21 APEC economies and applies quantile techniques to examine how institutions and associated factors impact pollution at various quantiles.

\section{Data, Methods, and Results}

\section{A. Data collection}

The empirical evidence we find is based on 21 APEC economies from 2000 to 2019. Our model considers carbon emissions ( $\mathrm{co} 2$ ) as the outcome variable, followed by several important variables in terms of oil consumption (oil), government expenditures on education (geed), the perception of corruption (cpi), growth $(g d p)$, economic freedom (ef), governance (goe), regulatory quality $(r q)$, and human development (hdi). We consider oil consumption, education, and corruption to be the main explanatory variables, as well as a set of control variables. The specification for this study is as follows:

$$
\begin{aligned}
l c o 2_{i t}= & \alpha_{0}+\alpha_{1} \text { loil }_{i t}+\alpha_{2} \text { lgeed }_{i t} \\
& +\alpha_{3} l c p i_{i t}+\alpha_{4} C V_{i t}+\varepsilon_{i t}
\end{aligned}
$$

where $i$ indicates each of the 21 countries, $t$ indicates the years 2000 to 2019, $C V$ indicates the control variables, $\alpha_{i}$ are the parameters, and $\varepsilon_{i t}$ is the error term. The data regarding carbon emissions and oil consumption are obtained from the BP Annual Statistical database. Information re- garding government expenditures on education, economic growth, governance effectiveness, and regulatory quality are taken from the databases of the World Development Indicators and World Governance Indicators of the World Bank. Further, we collect information on corruption, economic freedom, and human development from the APEC database. All data are collected on an annual basis and converted to natural logarithms to avoid spurious regression issues.

\section{B. Methods and results}

Table 1 reports the correlations of the variables. Our results suggest that oil consumption and carbon emissions are positively correlated. They state that too much dependence on oil in the APEC region has resulted in higher emissions intensity over the years. In addition, increases in growth and economic freedom are positively correlated with oil consumption. However, we find that increases in government effectiveness and regulatory quality in terms of accountability lead to a decline in carbon emissions.

We estimate Eq. (1), as well as a quantile regression, to determine how institutional factors shape the oil consumption-pollution dynamics in the region. Our regression estimates (reported in Table 2) show a positive significant association between oil consumption and emissions at the $1 \%$ level of significance. Surprisingly, we find that literacy positively influences emissions intensity. The results indicate that high literacy propelled by economic growth and a rise in income result in greater pollution in the region. However, we find little evidence that improvements in economic freedom and regulatory quality lessen emissions over the years. This finding indicates that economies with better environmental regulatory quality along with the adoption of 
Table 2. Regression results

\begin{tabular}{|c|c|c|c|}
\hline Model & OLS & $\begin{array}{l}\text { FGLS with heteroscedastic } \\
\text { panel }\end{array}$ & $\begin{array}{l}\text { FGLS with heteroscedastic } \\
\text { panel cross-sectional } \\
\text { correlation }\end{array}$ \\
\hline & I & II & III \\
\hline loil & $\begin{array}{l}0.201^{*} \\
(0.043)\end{array}$ & $\begin{array}{l}0.125^{*} \\
(0.019)\end{array}$ & $\begin{array}{l}0.202^{*} \\
(0.003)\end{array}$ \\
\hline lgeed & $\begin{array}{l}0.218^{*} \\
(0.060)\end{array}$ & $\begin{array}{l}-0.084^{*} \\
(0.027)\end{array}$ & $\begin{array}{l}0.218^{*} \\
(0.002)\end{array}$ \\
\hline Icpi & $\begin{array}{l}0.465 \\
(0.365)\end{array}$ & $\begin{array}{l}0.527^{*} \\
(0.166)\end{array}$ & $\begin{array}{l}0.401^{*} \\
(0.023)\end{array}$ \\
\hline $\lg d p$ & $\begin{array}{l}-0.176 \\
(0.119)\end{array}$ & $\begin{array}{l}0.013 \\
(0.012)\end{array}$ & $\begin{array}{l}-0.140^{*} \\
(0.007)\end{array}$ \\
\hline lef & $\begin{array}{l}-1.374^{*} \\
(0.390)\end{array}$ & $\begin{array}{l}-1.170^{*} \\
(0.266)\end{array}$ & $\begin{array}{l}-1.274^{*} \\
(0.059)\end{array}$ \\
\hline goe & $\begin{array}{l}0.420^{*} \\
(0.122)\end{array}$ & $\begin{array}{l}0.079^{* *} \\
(0.042)\end{array}$ & $\begin{array}{l}0.375^{*} \\
(0.009)\end{array}$ \\
\hline rq & $\begin{array}{l}-0.501^{*} \\
(0.127)\end{array}$ & $\begin{array}{l}-0.196^{*} \\
(0.045)\end{array}$ & $\begin{array}{l}-0.445^{*} \\
(0.010)\end{array}$ \\
\hline hdi & $\begin{array}{l}-2.333^{*} \\
(0.692)\end{array}$ & $\begin{array}{l}-0.632^{*} \\
(0.284)\end{array}$ & $\begin{array}{l}-2.268^{*} \\
(0.265)\end{array}$ \\
\hline Constant & $\begin{array}{l}3.302^{*} \\
(0.553)\end{array}$ & $\begin{array}{l}3.284^{*} \\
(0.241)\end{array}$ & $\begin{array}{l}3.179^{*} \\
(0.044)\end{array}$ \\
\hline Observations & 420 & 420 & 420 \\
\hline F-statistic/Wald statistic & $13.62^{*}$ & $218.51^{*}$ & $388.10^{*}$ \\
\hline
\end{tabular}

This table reports the regression results. The estimates suggest that a rise in oil consumption and an improved regulatory quality result in high and low emissions, respectively. (*), ${ }^{(* * *)}$ and $(* * *)$ indicate $1 \%, 5 \%$ and $10 \%$ levels of significance respectively.

sustainable economic freedom help decrease emissions over the years.

We further seek to examine the impacts of oil consumption and institutional factors on carbon emissions by a quantile regression approach. This enables us to see the impacts on emissions at different intervals. We note that oil consumption impacts emissions significantly at higher quantiles (see Table 3). Expenditures on education help moderate pollution at higher quantiles.

On the other hand, we find that increases in corrupt practices help increase pollution, while increases in regulatory quality and economic freedom help dampen pollution at all quantiles. However, no significant relation is observed between either the $g d p$ or $h d i$ variables and emissions at different quantiles. Surprisingly, we note that marginal improvements in government effectiveness results in more pollution. This is because of excessive stress on industrialization and coal-led energy consumption and extraction in the APEC region.

\section{Robustness checks}

Since the empirical results from least squares estimates are subject to endogeneity issues, we apply the generalized methods of moments to account for endogeneity and serial correlation issues in the regression estimates.

In line with previous estimates, we also see that an increase in oil consumption contributes positively toward emissions (see Table 4). Similarly, rising literacy and cor- ruption levels result in more carbon emissions in the long run. However, we find similar findings in terms of rising human development and regulatory quality, which significantly help reduce emissions. These results overall imply that improvements in governance and institutional mechanisms are key to controlling emissions, along with improved income and human development. Our additional results are found to be robust and consistent.

\section{Concluding Remarks}

This study demonstrates the importance of institutional factors in determining oil consumption-pollution dynamics. Moreover, a few important factors such as governance, corruption, transparency, human capital, and economic freedom matter more to the evolution of environmental protection in the APEC region. As evident from our analysis, improved governance structure and greater economic freedom facilitate better green recovery for the region. Some of our models even exhibit a stronger association between pollution and oil consumption despite higher growth and human development. Compared to least squares estimates, our generalized method of moments results even show that a marginal increase in human development and literacy result in higher pollution. Overall, these results suggest that institutional factors, literacy, and governance impact pollution, in addition to increases in growth and development. Despite the lack of earlier evidence on APEC, our empirical modeling suggests further ways of examining 
Table 3. Quantile Estimates

\begin{tabular}{|c|c|c|c|}
\hline \multirow[t]{2}{*}{ Model } & $25^{\text {th }}$ quantile & $50^{\text {th }}$ quantile & $75^{\text {th }}$ quantile \\
\hline & I & II & III \\
\hline loil & $\begin{array}{c}0.172 \\
(0.150)\end{array}$ & $\begin{array}{l}0.064^{*} \\
(0.012)\end{array}$ & $\begin{array}{l}0.058^{*} \\
(0.018)\end{array}$ \\
\hline lgeed & $\begin{array}{c}-0.054 \\
(0.047)\end{array}$ & $\begin{array}{c}-0.00^{*} \\
(0.024)\end{array}$ & $\begin{array}{c}-0.107^{*} \\
(0.025)\end{array}$ \\
\hline Icpi & $\begin{array}{c}0.702 \\
(0.603)\end{array}$ & $\begin{array}{l}0.352^{*} \\
(0.107)\end{array}$ & $\begin{array}{l}0.477^{*} \\
(0.152)\end{array}$ \\
\hline $\lg d p$ & $\begin{array}{l}-0.093 \\
(0.092)\end{array}$ & $\begin{array}{c}-0.004 \\
(0.003)\end{array}$ & $\begin{array}{c}0.038 \\
(0.032)\end{array}$ \\
\hline lef & $\begin{array}{l}-1.251 \\
(1.106)\end{array}$ & $\begin{array}{c}-0.557^{*} \\
(0.156)\end{array}$ & $\begin{array}{c}-0.656^{*} \\
(0.162)\end{array}$ \\
\hline goe & $\begin{array}{c}0.026 \\
(0.023)\end{array}$ & $\begin{array}{l}0.170^{*} \\
(0.035)\end{array}$ & $\begin{array}{l}0.176^{*} \\
(0.051)\end{array}$ \\
\hline rq & $\begin{array}{l}-0.126 \\
(0.112)\end{array}$ & $\begin{array}{c}-0.228^{*} \\
(0.037)\end{array}$ & $\begin{array}{c}-0.295^{*} \\
(0.053)\end{array}$ \\
\hline hdi & $\begin{array}{l}-1.135 \\
(1.120)\end{array}$ & $\begin{array}{c}-0.172 \\
(0.166)\end{array}$ & $\begin{array}{c}0.289 \\
(0.280)\end{array}$ \\
\hline Constant & $\begin{array}{l}3.404^{*} \\
(1.706)\end{array}$ & $\begin{array}{l}2.169^{*} \\
(0.161)\end{array}$ & $\begin{array}{l}2.446^{*} \\
(0.231)\end{array}$ \\
\hline Pseudo $\mathrm{R}^{2}$ & 0.076 & 0.108 & 0.124 \\
\hline
\end{tabular}

This table reports the quantile regression estimates. The results suggest that higher oil consumption results in higher emissions at higher quantiles, while improved economic freedom and regulatory quality lead to lower emissions at higher quantiles. $\left({ }^{*}\right),\left({ }^{* * *}\right)$ and $\left({ }^{* * * *}\right)$ indicate $1 \%, 5 \%$ and $10 \%$ levels of significance, respectively.

the role of institutions in a detailed manner.

\section{Acknowledgement}

Authors are grateful to the anonymous referee for useful comments. 
Table 4. GMM Estimates

\begin{tabular}{|c|c|c|}
\hline & 1 & II \\
\hline $\operatorname{lco} 2(-1)$ & $\begin{array}{l}0.939^{*} \\
(0.074)\end{array}$ & $\begin{array}{l}0.778^{*} \\
(0.147)\end{array}$ \\
\hline loil & $\begin{array}{l}0.020^{*} \\
(0.009)\end{array}$ & $\begin{array}{l}0.011^{*} \\
(0.004)\end{array}$ \\
\hline Igeed & $\begin{array}{l}0.019^{* *} \\
(0.011)\end{array}$ & $\begin{array}{l}0.014^{* *} \\
(0.008)\end{array}$ \\
\hline Icpi & $\begin{array}{l}0.038^{*} \\
(0.009)\end{array}$ & $\begin{array}{c}0.031 \\
(0.006)\end{array}$ \\
\hline $\lg d p$ & $\begin{array}{l}0.009^{*} \\
(0.003)\end{array}$ & $\begin{array}{l}0.013^{*} \\
(0.003)\end{array}$ \\
\hline lef & $\begin{array}{l}-0.041 \\
(0.040)\end{array}$ & $\begin{array}{l}-0.071 \\
(0.050)\end{array}$ \\
\hline goe & $\begin{array}{c}0.007 \\
(0.006)\end{array}$ & $\begin{array}{l}0.020^{*} \\
(0.006)\end{array}$ \\
\hline rq & $\begin{array}{l}-0.013^{*} \\
(0.006)\end{array}$ & $\begin{array}{l}-0.025^{*} \\
(0.005)\end{array}$ \\
\hline hdi & $\begin{array}{l}-0.046 \\
(0.044)\end{array}$ & $\begin{array}{c}-0.276^{* * *} \\
(0.180)\end{array}$ \\
\hline Constant & $\begin{array}{c}0.254 \\
(0.247)\end{array}$ & $\begin{array}{c}0.771 \\
(0.563)\end{array}$ \\
\hline Number of instruments & 27 & 45 \\
\hline Sargan test $p$-value & 0.748 & 0.890 \\
\hline AR (1) p-value & 0.069 & 0.102 \\
\hline AR (2) p-value & 0.372 & 0.270 \\
\hline
\end{tabular}

This table reports the GMM estimates. The estimates suggest that rising regulatory quality reduces emissions, while government effectiveness does not significantly influence emissions in the region. $\left(^{*}\right),\left({ }^{* * *}\right)$ and $\left({ }^{* * * *}\right)$ indicate $1 \%, 5 \%$ and $10 \%$ levels of significance, respectively. 


\section{REFERENCES}

Ali, H. S., Zeqiraj, V., Lin, W. L., Law, S. H., Yusop, Z., Bare, U. A. A., \& Chin, L. (2019). Does quality institutions promote environmental quality? Environmental Science and Pollution Research, 26(11), 10446-10456. https://doi.org/10.1007/s11356-019-04 $\underline{670-9}$

Burke, M. J., \& Stephens, J. C. (2018). Political power and renewable energy futures: A critical review. Energy Research \& Social Science, 35, 78-93. https://d oi.org/10.1016/j.erss.2017.10.018

Egbetokun, S., Osabuohien, E., Akinbobola, T., Onanuga, O. T., Gershon, O., \& Okafor, V. (2020). Environmental pollution, economic growth and institutional quality: Exploring the nexus in Nigeria. Management of Environmental Quality: An International Journal.

Franco, S., Mandla, V. R., \& Rao, K. R. M. (2017). Urbanization, energy consumption and emissions in the Indian context A review. Renewable and Sustainable Energy Reviews, 71, 898-907. https://doi.o rg/10.1016/i.rser.2016.12.117

Fredriksson, P. G., \& Svensson, J. (2003). Political instability, corruption and policy formation: The case of environmental policy. Journal of Public Economics, 87(7-8), 1383-1405. https://doi.org/10.1016/s0047-27 27(02)00036-1

Ibrahim, M. H., \& Law, S. H. (2016). Institutional Quality and CO2 Emission-Trade Relations: Evidence from Sub-Saharan Africa. South African Journal of Economics, 84(2), 323-340. https://doi.org/10.1111/sa je. 12095

Khan, H., Weili, L., \& Khan, I. (2021). Recent advances in energy usage and environmental degradation: Does quality institutions matter? A worldwide evidence. Energy Reports, 7, 1091-1103. https://doi.or g/10.1016/i.egyr.2021.01.085

Mavragani, A., Nikolaou, I. E., \& Tsagarakis, K. P. (2016). Open economy, institutional quality, and environmental performance: A macroeconomic approach. Sustainability, 8(7), 601. https://doi.org/1 $\underline{0.3390 / \mathrm{su} 8070601}$
Mehrara, M., Rezaei, S., \& Razi, D. H. (2015). Determinants of renewable energy consumption among ECO countries; based on Bayesian model averaging and weighted-average least square. International Letters of Social and Humanistic Sciences, 54, 96-109. https://doi.org/10.18052/www.scipress.co $\mathrm{m} / \mathrm{ilshs.54.96}$

Olanrewaju, B. T., Olubusoye, O. E., Adenikinju, A., \& Akintande, O. J. (2019). A panel data analysis of renewable energy consumption in Africa. Renewable Energy, 140, 668-679. https://doi.org/10.1016/j.renen e.2019.02.061

Singhania, M., \& Saini, N. (2021). Demystifying pollution haven hypothesis: Role of FDI. Journal of Business Research, 123, 516-528. https://doi.org/10.10 16/j.jbusres.2020.10.007

Tamazian, A., Chousa, J. P., \& Vadlamannati, K. C. (2009). Does higher economic and financial development lead to environmental degradation: Evidence from BRIC countries. Energy Policy, 37(1), 246-253. https://doi.org/10.1016/i.enpol.2008.08.025

Xie, X., Huo, J., \& Zou, H. (2019). Green process innovation, green product innovation, and corporate financial performance: A content analysis method. Journal of Business Research, 101, 697-706. https://do i.org/10.1016/j.jbusres.2019.01.010

Yameogo, C. E., Omojolaibi, J. A., \& Dauda, R. O. (2020). Economic Globalisation, Institutions and Environmental Quality in Sub-Saharan Africa. Research in Globalization, 100035.

Zhao, X., \& Luo, D. (2017). Driving force of rising renewable energy in China: Environment, regulation and employment. Renewable and Sustainable Energy Reviews, 68, 48-56. https://doi.org/10.1016/j.rser.201 $\underline{6.09 .126}$ 